\title{
"Modeling of structural and temporal characteristics in the corporate securities market of Ukraine"
}

\begin{tabular}{|c|c|}
\hline \multirow{7}{*}{ AUTHORS } & Mykhailo Kuzheliev (D) https://orcid.org/0000-0002-7895-7879 \\
\hline & R http://www.researcherid.com/rid/G-6791-2019 \\
\hline & Ihor Rekunenko (D https://orcid.org/0000-0002-1558-629X \\
\hline & R http://www.researcherid.com/rid/P-3964-2014 \\
\hline & Antonina Boldova (D https://orcid.org/0000-0001-5116-963X \\
\hline & Maksym Zhytar (D https://orcid.org/0000-0003-3614-0788 \\
\hline & Serhij Stabias (D) https://orcid.org/0000-0003-2758-5662 \\
\hline ARTICLE INFO & $\begin{array}{l}\text { Mykhailo Kuzheliev, Ihor Rekunenko, Antonina Boldova, Maksym Zhytar and } \\
\text { Serhij Stabias (2019). Modeling of structural and temporal characteristics in the } \\
\text { corporate securities market of Ukraine. Investment Management and Financial } \\
\text { Innovations, 16(2), 260-269. doi:10.21511/imfi.16(2).2019.22 }\end{array}$ \\
\hline DOI & http://dx.doi.org/10.21511/imfi.16(2).2019.22 \\
\hline RELEASED ON & Thursday, 20 June 2019 \\
\hline RECEIVED ON & Tuesday, 09 April 2019 \\
\hline \multirow[t]{2}{*}{ ACCEPTED ON } & Tuesday, 04 June 2019 \\
\hline & $(\mathrm{cc}) \mathrm{EY}$ \\
\hline LICENSE & $\begin{array}{l}\text { This work is licensed under a Creative Commons Attribution } 4.0 \text { International } \\
\text { License }\end{array}$ \\
\hline JOURNAL & "Investment Management and Financial Innovations" \\
\hline ISSN PRINT & $1810-4967$ \\
\hline ISSN ONLINE & $1812-9358$ \\
\hline PUBLISHER & LLC “Consulting Publishing Company "Business Perspectives" \\
\hline FOUNDER & LLC “Consulting Publishing Company "Business Perspectives" \\
\hline
\end{tabular}

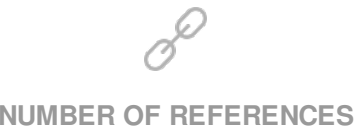

30
NUMBER OF FIGURES

3
NUMBER OF TABLES

1

(C) The author(s) 2022. This publication is an open access article. 


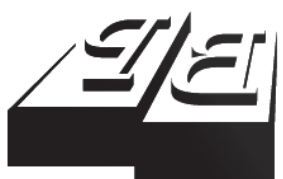

BUSINESS PERSPECTIVES

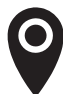

LLC "CPC "Business Perspectives" Hryhorii Skovoroda lane, 10, Sumy, 40022, Ukraine

www.businessperspectives.org

Received on: $9^{\text {th }}$ of April, 2019 Accepted on: $4^{\text {th }}$ of June, 2019

(C) Mykhailo Kuzheliev, Ihor Rekunenko, Antonina Boldova, Maksym Zhytar, Serhij Stabias, 2019

Mykhailo Kuzheliev, Doctor of Economics, Professor, Director of the Scientific and Research Institute of Finance and Banking, University of the State Fiscal Service of Ukraine, Ukraine.

Ihor Rekunenko, Doctor of Economics, Professor, Professor of the Department of Finance, Banking and Insurance, Sumy State University, Ukraine.

Antonina Boldova, Ph.D. in Pedagogy, Associate Professor of the Department of Financial Market, University of the State Fiscal Service of Ukraine, Ukraine.

Maksym Zhytar, Ph.D. in Economics, Associate Professor of the Department of Finance named after L. L. Tarangul, University of the State Fiscal Service of Ukraine, Ukraine.

Serhij Stabias, Postgraduate Student of the Department of Finance and Banking, Donetsk Nationa University named after V. Stus, Ukraine.

\section{(ㄷ) (i)}

This is an Open Access article, distributed under the terms of the Creative Commons Attribution 4.0 International license, which permits unrestricted re-use, distribution, and reproduction in any medium, provided the original work is properly cited.
Mykhailo Kuzheliev (Ukraine), Ihor Rekunenko (Ukraine), Antonina Boldova

(Ukraine), Maksym Zhytar (Ukraine), Serhij Stabias (Ukraine)

\section{AND TEMPORAL CHARACTERISTICS IN THE CORPORATE SECURITIES MARKET OF UKRAINE}

\begin{abstract}
The development of the corporate securities market and the effective use of tools for its regulation cannot be achieved without models and methods of economic and mathematical modeling. The aim is to analyze and systematize the structural and temporal characteristics of the corporate securities market in Ukraine by applying economic and mathematical modeling methods. In the paper, linear interpolation is used to assess the temporal characteristics of corporate securities under market uncertainty. Descriptive and simulation modeling methods are also applied to carry out a formal description of the process of evaluating the structural characteristics of securities. The result of the study involves developing a descriptive model to analyze the structural and temporal characteristics of the Ukrainian corporate securities market. The approbation of the proposed model makes it possible to draw the following conclusions. First, Perspektiva Stock Exchange, Ukrainian Exchange and PFTS - the First Stock Trading System, are the most important trading platforms. They are determined by the monthly bidding dynamics and can belong to the same group - active players in the corporate securities market of Ukraine. Second, in terms of endogenous priorities, the development of the corporate securities market is mostly influenced by inflation rates (consumer price index), economic development indicators (key branches production index) and interest rates on alternative financial instruments (new deposit interest rates of deposit-taking corporations). Third, the rate of corporate securities issue and the native currency rate do not significantly affect the corporate securities market development, in particular, the former is characterized by a slight negative impact, and the latter - by a slight positive impact on the price dynamics.
\end{abstract}

Keywords

\section{JEL Classification}

shares, descriptive model, economic and mathematical modeling, securities profitability, financial market

\section{INTRODUCTION}

The Ukrainian securities market is a multifaceted socio-economic system that promotes capital accumulation for investment in production and social sectors, restructuring of the economy, the positive dynamics of the society's social structure, increasing the welfare of every citizen through the possession and free disposal of securities, the psychological readiness of the population to market relations. The market mechanism is always characterized by instability, as it is implemented through the behavior of market counterparties, whose interests, as a rule, do not coincide. Elimination or limitation of such immanence usually results from the effective management in financial markets, where excessive volatility can be localized via adequate methods. Their development and implementation specify the relevance of the chosen research problem, focusing on theoretical aspects and analysis procedures, as well as management of structural and temporal characteristics in the Ukrainian corporate securities market. 


\section{LITERATURE REVIEW}

The analysis of structural and temporal characteristics in the corporate securities market can be considered in terms of fundamental and technical approaches. In economic theory, they are also characterized as "the theory of a solid foundation" and "the pipe dream theory". In this case, the technical analysis is aimed at identifying shortterm trends in the share prices and provides for a rather slow reaction of prices in response to the fundamental factors effect. Technical analysts get the information they need to make decisions by analyzing historical price dynamics, while ignoring the fundamental properties.

Charles Dow (who suggested the use of the Dow Jones Industrial Average) and William Hamilton (the author of The Stock Market Barometer) (Hamilton, 1926) can be considered the founders of technical analysis. The Dow's ideas were further developed by his followers: Elliott (1939), Gann (1927), Lane (2007), Wilder (1978), Williams (1938), Bongaerts, de Jong, and Driessen (2011). Murphy (1986), Nison (2011), Ponta, Pastore, and Cincotti (2006) studied the principles of analyzing the structural and temporal characteristics of the market. In addition, a fairly large number of studies have revealed that, based on the analysis of past price fluctuations, the future movement of quotes cannot be determined, which calls into question the effectiveness of using technical analysis. It should be noted, however, that in practice this approach is often used by stock market players. Fundamental analysis is used to measure the fair value of a financial instrument based on an analysis of the issuer's performance, as well as external factors affecting it.

Fundamental analysis focuses on long-term investment, because it is based on the identification of long-term structural and temporal characteristics of securities in the market. The founders of the fundamental analysis are Benjamin Graham and David Dodd (Security Analysis, 1934) and John Burr Williams (The Theory of Investment Value, 1938). Further, Benjamin Graham himself implemented fundamental analysis. This helped him become a good investor. His most famous follower was Warren Edward Buffett. Fundamental analysis is real only in the environment where the state uses a market economy, where any external and internal factors that are suppressed by the government influence the sectors. In addition, the impossibility of fundamental analysis is due to the fact that the formation of prices is affected by a huge number of factors, including random and unpredictable ones, and it is impossible to take into account all factors in principle, especially that it is not known in advance how any given event can influence the price (for example, a natural disaster, on the one hand, harms the national economy, which should lead to a fall in the native currency rate, etc.).

One of the key factors that determine the ineffective use of fundamental analysis of the market structural and temporal characteristics is the following statement: Markets may set "false prices" in the short term, but they (markets) admit their own "mistake" and the "correct" price will eventually be reached. Thus, Hayes (2008), the representative of the neo-Keynesian school, questioned the assertion that prices in financial markets should reflect the value of an asset, that is its internal (fundamental) value. While justifying, he paid attention to the behavior of rational agents in the market and confirmed that the choice of the agent is based not on the personal preferences of the experiment participants, but on an attempt to predict the final result of the process based on other rational agents' considerations. Interpolation of this concept to the securities market shows that since agents usually do not take into account their advantages and make decisions based on the advantages of other people, then the price of assets is determined not on the basis of their belief about the compliance of this price with the fundamental value for this asset, but based on the belief that all other agents consider this asset value as its corresponding fundamental value. However, fundamental analysis is actively used by professional corporate securities market players.

Both approaches are used to analyze further movement of prices for a particular financial instrument, the findings of which can be used by investors to obtain the desired income.

Yartey studied factors of the structural and temporal market characteristics. He divided the factors into two main groups: macroeconomic and institutional ones (Yartey, 2008). Macroeconomic fac- 
tors include income level, gross domestic investment, the banking sector development, the inflow of private capital, and macroeconomic stability. Institutional factors include political risks, the level of law and order, and the bureaucratic procedures of the state apparatus.

Shkolnyk (2008) follows the similar view while considering factors of the financial market development. According to the researcher, they are shaped influenced by the institutional environment and the peculiarities of economic relations in the country.

Mirkin (2002) highlights "fundamental factors" and considers those having the greatest impact on the long-term securities market: ownership structure, models of economic behavior of the population, sectoral structure of macroeconomics, financial depth, influence of international markets, etc.

Ponta, Pastore, and Cincotti (2006) investigate static factors taking into account the mutual correlation between the income of different shares, while the general trends are investigated with dispersion-covariance price matrix.

At the same time, the analysis of the works contained in the literature review shows that the problems of the corporate securities market development in Ukraine, namely managing its structural and temporal characteristics, need further research.

\section{Aims}

The purpose of the study is to analyze and systematize structural and temporal characteristics in the Ukrainian corporate securities market, explore their impact on the macroeconomic indicators of the country's development based on economic and mathematical modeling.

\section{METHODS}

The article uses a method of linear interpolation to assess the temporal characteristics of corporate securities under market uncertainty. Methods of descriptive and simulation modeling are also applied to make a formal description of the process of evaluating the structural characteristics of securities.

\section{RESULTS}

Financial markets as a whole, as well as the corporate securities market, are economic systems that grow very rapidly. The variety of assets and relevant information presented in the financial markets by various types of financial instruments and market entities is characterized by high uncertainty. The prices of individual corporate securities (CSs) and their operations are subject to the multi-faceted impact of a large number of factors, which further complicates the processes of analysis, modeling and forecasting of key trends. That is, the very fast development of financial markets in various aspects of their functioning is a key impetus to the development of theory and leading approaches to the modeling of economic processes, namely: probability theory, mathematical statistics, econometrics, economic and mathematical modeling, simulation, etc. Thus, in the modern information economic space, when the volumes of information increase exponentially, it is impossible to consider the systems of regulating the corporate securities market in isolation from modern methods of economic and mathematical modeling, econometric forecasting tools and big data analysis (Lysenko \& Zherlitsyn (Eds.), 2017; Yartey, 2008; Kuzheliev \& Britchenko, 2016).

It is expedient to propose an author's classification of key methods of economic-mathematical modeling, which determines the special nature of definition of structural and temporal characteristics in the corporate securities market. Taking into account the previous studies on this subject, one can formulate the conceptual approach to modeling the structural and temporal characteristics in the corporate securities market (see Figure 1).

According to the defined conceptual framework, consider the process of development and implementation of the management models for the processes of functioning of the Ukrainian corporate securities market.

The first stage in modeling any system is collecting and initial processing of information. At this stage, Method 1 and Method 2 are used. That is, the statistically significant information is selected and the sampling volumes are reduced due to the grouping of similar statistical data. 
Stage 1. Collecting primary information and defining the law of distribution of relevant indicators. When collecting primary information, the following requirements regarding the correct information are met:

- $\quad$ sufficient amount of information (at least 40);

- structural comparability (normalization).

If the index subject to normalization is a positive value, then its value is normalized using logarithmation as follows (Mints, 2017):

$$
\bar{a}_{i}=\log \left(a_{i}\right)
$$

where $a_{i}$ - element value from a multiplicity of elements.

The logarithm basis is not important, but the natural logarithm is usually applied.
If the multiplicity of elements is presented as negative and positive values, then:

$$
\bar{a}_{i}=\frac{a_{i}-\min (A)}{\max (A)-\min (A)},
$$

where $a_{i}$ - element value from a multiplicity of elements $A, A$-multiplicity of elements.

In order to fill the missing elements in the time series, linear interpolation is used (Mirkin, 2002; Meijers, Nomaler, \& Verspagen, 2018):

$$
a=a_{i}+\frac{t-t_{i}}{t_{i+1}-t_{i}}\left(a_{i+1}-a_{i}\right),
$$

where $a_{i}$ and $a_{i+1}$ - the element value from the multiplicity of elements $A$ before and after the element, whose value is to be found, $a_{i}$ and $a_{i+1}$ - the time period before and after the element, whose value is to be found.

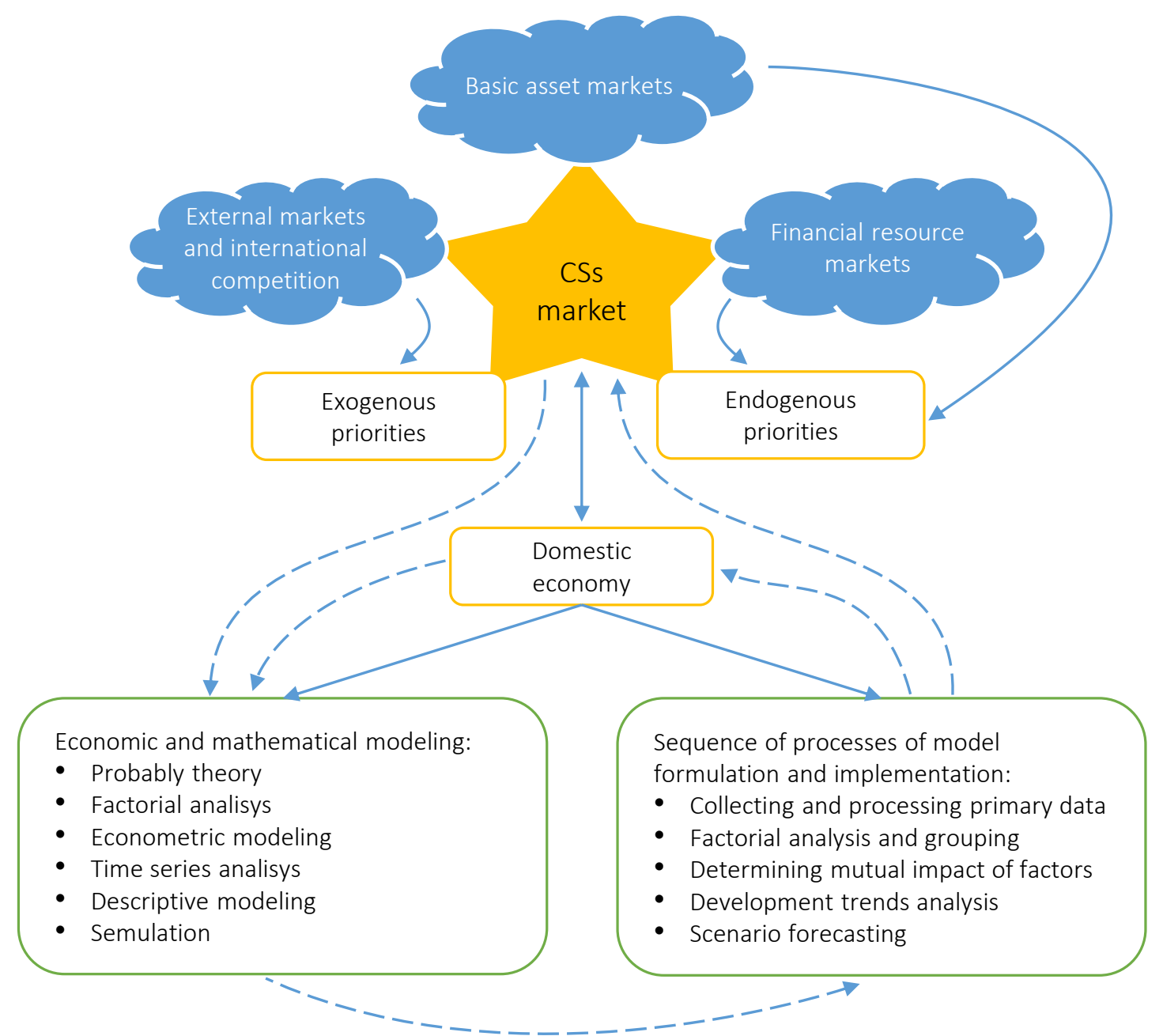

Figure 1. Modeling of structural and temporal characteristics in the corporate securities market 
Stage 2. Box-and-whisker plot is an important data grouping tool used in this stage. On the same chart, it shows the data on the average, the maximum, and the minimum for the sample, the first and the second quantiles. Parametric development of this approach includes the methods of dispersion and cluster analyses, which are used to classify input data in more detail.

Stage 3. The comparability of structural and temporal characteristics of the corporate securities market is usually determined through indicators (Tarasiuk, 2013; Shkliayev, 2012):

- mathematical expectation, mean value, mode, median value, etc.;

- mean deviation, semivariation, dispersion, etc.;

- moving mean, especially during data narrowing and trend identification; and

- growth rates.

Most often, at the stage of determining the essential statistical characteristics, parametric methods based on calculating the universal statistical criterion of Pearson's chi-squared test $\left(x_{2}\right.$ criterion) are used. This makes it possible to accept or reject the hypothesis that the theoretical data set corresponds to the same as the sample population (Mirkin, 2002; Cherniak \& Stavytskyi, 2010; Shkliayev, 2012).

$$
x^{2}=\sum_{i=1}^{n} \frac{m_{i}-m_{i}^{\prime}}{m_{i}^{\prime}} .
$$

A specific tool for confirming the hypothesis about the normal distribution of the sample small data is the Shapiro-Wilk test, which is based on the corresponding statistical criterion (Ayvazian \& Mkhitarian, 2001; Shkliayev, 2012; Kuzheliev, Zherlitsyn, \& Zhytar, 2016):

$$
S W=\frac{\left(\sum_{i=1}^{n} a_{i} x_{i}\right)^{2}}{\sum_{i=1}^{n}\left(x_{i}-\bar{x}\right)^{2}} .
$$

Stage 4. Determining mutual impact of factors (correlation matrix, linear dependence, multiple factor analysis). This group of methods is used on the basis of tools for modern econometric analysis and forecasting, which in turn provides for the following algorithm of calculations:

- estimating values of the correlation matrix or matrix of pairwise coefficients of linear regression;

- determining the link significance;

- justifying the regression model coefficients.

The indicated calculations are based on the results of stages 1 to 3 , because it is based on the analysis of prepared (processed) data.

Stage 5. Scenario forecasting in the form of implementation of descriptive models (determining factor dependence, financial mathematics, etc.), construction of causal relationships diagrams, system-dynamic modeling, etc.

Given the determined dependencies in stages 3-4, which involves the definition of theoretical causal relationships and their proof based on a series of simulation experiments, the need to justify additional descriptive models is recognized.

Taking into account previous studies, the key causal dependencies of the dynamic model of the CSs market functioning can be presented as in Figure 2.

As can be seen from Figure 2, peculiarities of the corporate securities market functioning as an object of regulation are determined by the dynamic impact of the following factors: volumes of corporate securities issuance, a set of endogenous and exogenous priorities.

Using this chart of causal relations of the descriptive model of the corporate securities market functioning (see Figure 2) enables to assess and predict the specific development priorities and effectiveness of the basic regulatory instruments for most of the corporate securities markets.

Taking into account the research conducted and available information on the development of 
world and domestic corporate securities markets, data from 2014 to 2017 are considered, namely: the key indicators of the corporate securities market development are the price, volumes of issues and bids that are determined by the following variables: $x_{1}$ - the Ukrainian Stock Exchange index is a generalized index for estimating the price level for the corporate securities (CSs) (the weighted average price for CSs), the growth index before the previous month, calculated as the average daily logarithmic increase in prices, $x_{2}$ - volumes of CSs registered by the National Securities and Stock Market Commission, UAH mln.

Endogenous priorities and tools of influence of the CSs market of Ukraine: $x_{3}$ - Consumer Price Index (CPI), \% growth before the previous month - indicator of the inflation impact on the CS market dynamics, $x_{4}$ - interest rate on new deposits of deposit-taking corporations (except the National Bank of Ukraine (NBU)), $\%, x_{5}-\mathrm{NBU}$ discount rate, $\%$ - generalized index of financial asset minimum profitability, $x_{6}-$ GDP at actual prices, UAH bln, $x_{7}-$ key branches production index (IKSO), growth in $\%$ before the corresponding month of the previous year.
Exogenous priorities of the Ukrainian CSs market development: $x_{8}$ - average weighted rate of USD/UAH in the interbank foreign exchange market of Ukraine, UAH, $x_{9}$ - the index of the foreign (international) stock exchange (DJIAVE) is a generalized indicator of estimation of the price dynamics in world CSs markets, growth index before the previous month, calculated as the average daily logarithmic increase in prices, $x_{10}$ - balance of stocks of direct investment, taken into account at the price of the last transaction according to the NBU, USD billions.

The sources of primary information on these indicators are the data of the State Statistics Service of Ukraine (State Statistics Service of Ukraine, n.d.), the National Securities and Stock Market Commission (National Securities and Stock Market Commission, n.d.), the National Bank of Ukraine (National Bank of Ukraine, n.d.), the First Stock Trading System (PFTS ua-exchange, n.d.), the World Bank (The World Bank, n.d.), and the S\&P Rating (S\&P Global, n.d.).

Preliminary data analysis showed that only $x_{1}$, $x_{4}, x_{6}$, and $x_{9}$, according to the Shapiro-Wilk test, corresponded to the normal distribution law, namely:

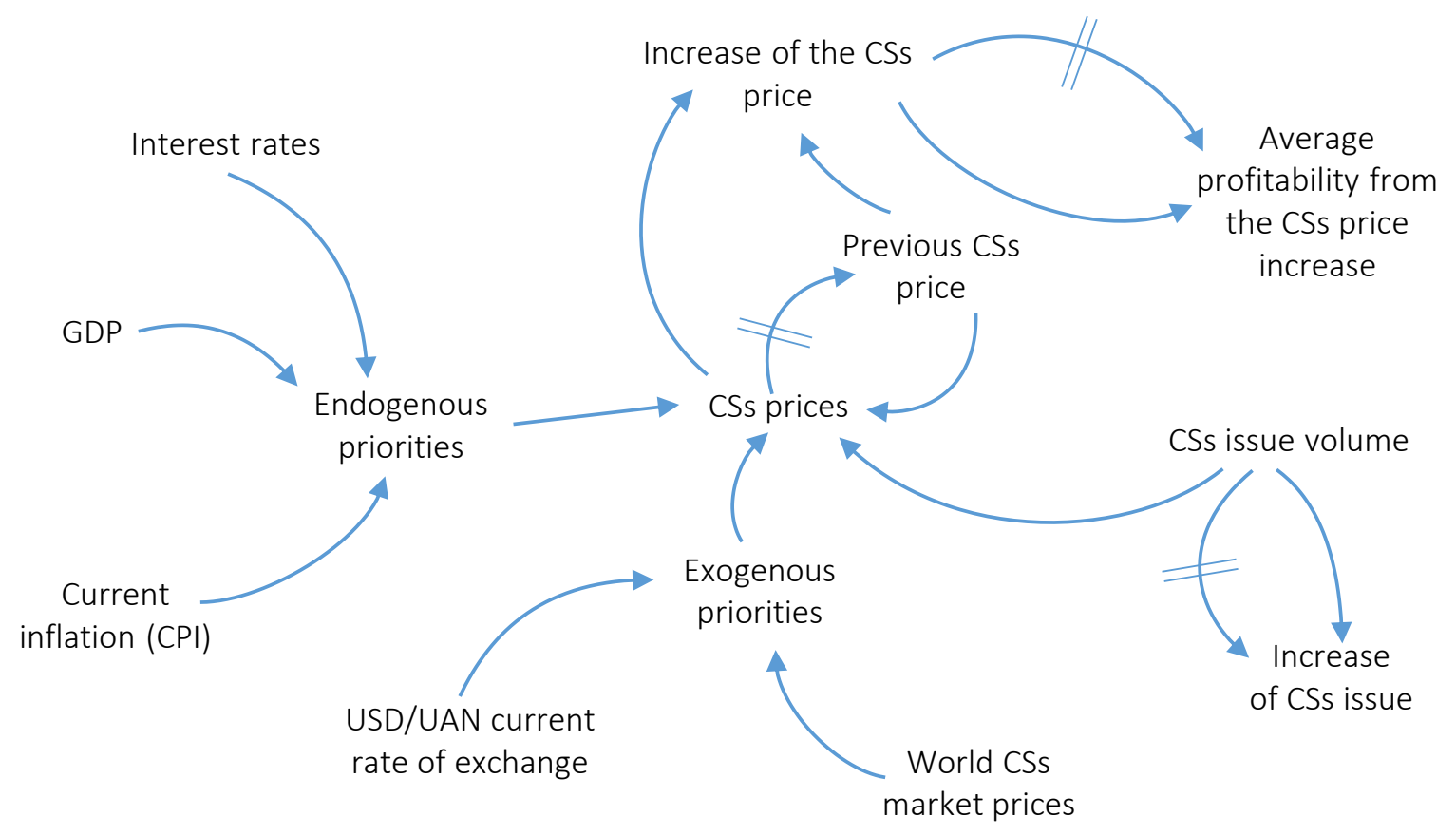

Figure 2. Causal relationships of the descriptive model of the Ukrainian CS market functioning 
Shapiro-Wilk normality test

$$
\begin{aligned}
& \text { data: } x_{1} \\
& W=0.96752, p \text {-value }=0.1102 \\
& \text { data: } x_{4} \\
& W=0.97987, p \text {-value }=0.4117 \\
& \text { data: } x_{6} \\
& W=0.96234, p \text {-value }=0.6193 \\
& \text { data: } x_{9} \\
& W=0.97682, p \text {-value }=0.3093
\end{aligned}
$$

For other indicators, certain transformations were applied (normalization, tinkering, etc.).

$x_{2}$ is normalized using logarithmation:

Shapiro-Wilk normality test

$$
\begin{aligned}
& \text { data: } \log \left(x_{2}\right) \\
& W=0.9546, p \text {-value }=0.06112 .
\end{aligned}
$$

For $x_{3}, x_{5}, x_{7}$ a significant emission period of March 2015 to April 2015 has been identified. The corresponding estimates of the parametric test for the specified variables, excluding data from March and April 2015, are as follows:

\section{Shapiro-Wilk normality test}

data: $x_{3}$ (adjusted without March, 2015 and April, 2015)

$W=0.97287, p$-value $=0.2096$

data: $\log \left(x_{5}\right)$ (adjusted without March, 2015 and April, 2015)

$W=0.92765, p$-value $=0.07576$

data: $x_{7}$ (adjusted without March, 2015

and April, 2015)

$W=0.90888, p$-value $=0.03172$
Shapiro-Wilk normality test

data: $x_{8}$ (adjusted without the year 2014)

$W=0.90671, p$-value $=0.02012$

data: $x_{10}$ (adjusted without year 2014)

$W=0.94111, p$-value $=0.3966$

That is, the relevant data will be used for future analysis, adjusted without March 2015 and April 2015 values, as well as for $x_{8}$ and $x_{10}$, without the 2014 values.

In order to determine, in a preliminary manner, the mutual influence of variables, a correlation matrix is given based on the determined indicators and the corresponding adjustments carried out at stage 3 (Table 1).

As can be seen from Table 1, the most significant linear relationship between the growth rate of CSs profitability is shown only with the new deposit rates of deposit-taking corporations $\left(x_{4}\right)$ and the NBU discount rate $\left(x_{4}\right)$. In this case, the interaction of $x_{4}$ and $x_{4}$ is sufficiently close, that is why it is impossible to exclude one of them from the analysis without significantly reducing the simulation adequacy. The smallest value of the pairwise correlation coefficient is determined for the following variables: $x_{1}$ and $x_{9}$, which indicates a

\begin{tabular}{|c|c|c|c|c|c|c|c|c|c|c|}
\hline & $x_{1}$ & $x_{2}$ & $x_{3}$ & $x_{4}$ & $x_{5}$ & $x_{7}$ & $x_{9}$ & $x_{6}$ & $x_{10}$ & $x_{8}$ \\
\hline$x_{1}$ & 1.000 & -0.202 & 0.310 & -0.604 & -0.552 & 0.236 & 0.013 & 0.324 & -0.248 & 0.374 \\
\hline$x_{2}$ & -0.202 & 1.000 & 0.115 & -0.021 & 0.062 & -0.015 & 0.042 & -0.061 & 0.143 & -0.055 \\
\hline $\boldsymbol{x}_{3}$ & 0.310 & 0.115 & 1.000 & -0.228 & -0.194 & -0.332 & 0.047 & -0.259 & -0.088 & -0.148 \\
\hline$x_{4}$ & -0.604 & -0.021 & -0.228 & 1.000 & 0.881 & -0.294 & -0.220 & -0.535 & 0.405 & -0.392 \\
\hline $\boldsymbol{x}_{5}$ & -0.552 & 0.062 & -0.194 & 0.881 & 1.000 & -0.428 & -0.305 & -0.604 & 0.426 & -0.407 \\
\hline $\boldsymbol{x}_{7}$ & 0.236 & -0.015 & -0.332 & -0.294 & -0.428 & 1.000 & 0.333 & 0.569 & -0.643 & 0.816 \\
\hline $\boldsymbol{x}_{9}$ & 0.013 & 0.042 & 0.047 & -0.220 & -0.305 & 0.333 & 1.000 & 0.279 & -0.225 & 0.337 \\
\hline$x_{6}$ & 0.324 & -0.061 & -0.259 & -0.535 & -0.604 & 0.569 & 0.279 & 1.000 & -0.237 & 0.614 \\
\hline $\boldsymbol{x}_{10}$ & -0.248 & 0.143 & -0.088 & 0.405 & 0.426 & -0.643 & -0.225 & -0.237 & 1.000 & -0.485 \\
\hline$x_{8}$ & 0.374 & -0.055 & -0.148 & -0.392 & -0.407 & 0.816 & 0.337 & 0.614 & -0.485 & 1.000 \\
\hline
\end{tabular}
small impact of the information from the world stock markets on the CSs market. That is why, the corresponding indicator will be excluded from the basic descriptive model, $x_{2}$ and $x_{3}, x_{4}, x_{5}, x_{6}$, $x_{7}, x_{8}$. That is, the volume of CSs issue is almost not related to the volume of key economic indicators of the country's development, but is a specific factor in the corporate securities market, which

Table 1. Correlation matrix of key indicators of the Ukrainian CSs market development 


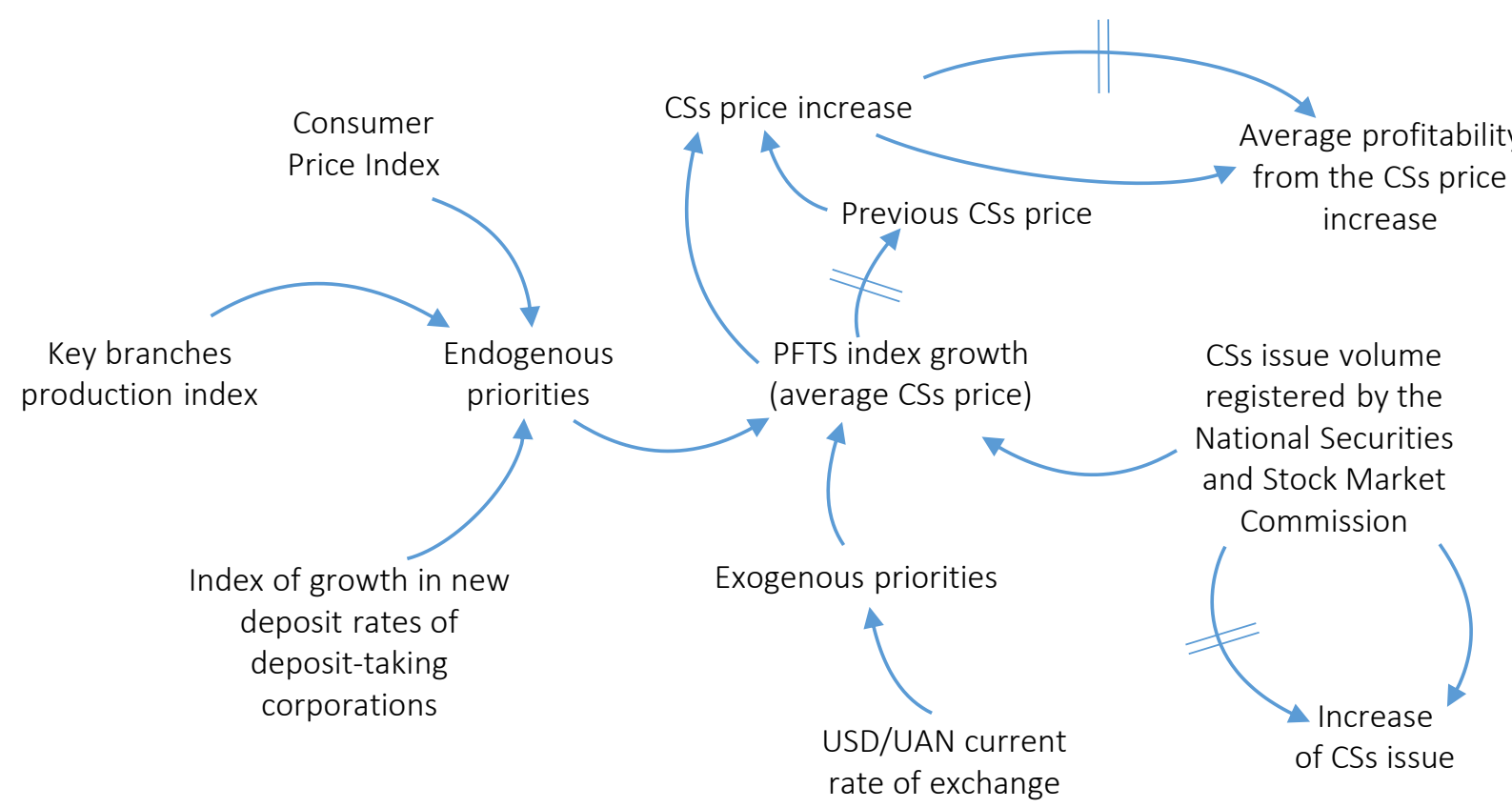

Figure 3. Causal relationships of the descriptive model of the Ukrainian CSs market functioning

statistically confirms the assumptions made within the proposed descriptive model, $x_{3}$ and $x_{10}$, that is, the balance of direct investment stocks is not related to the inflation rate, but is determined by fundamental factors (for example, key branches production index).

Significant relationship between factor variables (multicollinearity) is determined in cases with the following variables: $x_{4}$ and $x_{5}$, which is determined by the correlation between the relevant indicators of the level of deposit rates and the NBU discount rate (as a tool for adjusting the level of interest rates in the economy). Within the next model, only one of the indicators will be used as an internal influence factor, $x_{6}$, which is simultaneously related to $x_{4}, x_{5}$, and $x_{7}$. That is, within the limits of the above theoretical approach, the GDP indicator should be replaced with the related index, namely key branches production index, $x_{10}$ and $x_{6}$, indicating that the factors of external economic influence are connected because both are indicators of exogenous priorities, that is, during the analysis they can be converted into a combined indicator, for example, the balance of investment stocks in
UAH billion or the corresponding growth rate, $x_{10}$ and $x_{7}$, which indicates the dependence of producers on export-import operations. Within the model, the corresponding multicollinearity is overcome due to changes in the two previous exogenous priorities.

Considering the Stage 3 results makes it possible to specify the structural components of the descriptive model of the CSs market functioning (see Figure 3).

As can be seen from Figure 3, there are three groups of components in the model proposed:

- endogenous priorities that combine the consumer price index, index of growth in new deposit rates of deposit-taking corporations, and key branches production index;

- exogenous priorities, which are limited only by the indicator of the dynamics of the native currency rate to the USD;

- volume of CS issues, representing time series data. 


\section{CONCLUSION}

Thus, the research confirmed that, firstly, Perspektiva Stock Exchange, Ukrainian Exchange and PFTS (First Stock Trading System) are the most significant trading platforms. They are characterized by similar dynamics of monthly bids and they can be attributed to one group - active corporate securities market players.

Second, in terms of endogenous priorities, the development of the corporate securities market is mostly influenced by inflation rates (consumer price index), economic development indicators (key branches production index) and interest rates on alternative financial instruments (rates on new deposits of deposit-taking corporations). At the same time, the first two indicators have a positive impact on the CSs price growth, and the third affects negatively.

Third, the volumes of issuance of corporate securities and the native currency rate do not significantly affect the corporate securities market development, in particular, the former is determined by a slight negative impact on the price dynamics, and the latter - by a small positive impact

Thus, it can be argued that a balanced percentage of banking policy and the steady production development in key sectors of the economy are the key priorities of the corporate securities market development and their price increase (profitability).

\section{REFERENCES}

1. Ayvazian, S., \& Mkhitarian, V. (2001). Прикладная статистика. Том 1. Теория вероятностей и прикладная статистика [Prikladnaia statistika. Tom 1. Teoriia veroiatnostey $i$ prikladnaia statistika] (656 p.). Moscow: YuNITI-DANA. Retrieved from http:// ecsocman.hse.ru/text/33442857/

2. Bongaerts, D., de Jong, F., \& Driessen, J. (2011). An Asset Pricing Approach to Liquidity Effects in Corporate Bond Markets. Erasmus University, Tilburg University. Retrieved from https://www.4nations. org/papers/bongaertsdejongdriessen12.pdf

3. Cherniak, O. I., \& Stavytskyi, A. V. (2010). Динамічна економетрика [Dynamichna ekonometryka] (120 p.). Kyiv: VPCKU. Retrieved from http://www.andriystav.cc.ua/ukr/ Science/Books/_Book2.html

4. Elliott, R. N. (1939). The Financial World articles. Retrieved from http://raretradingbooks.blogspot. com/2012/09/the-original-12-financial-world.html

5. Gann, W. (1927). The Tunnel Thru the Air; or, Looking Back from 1940. New York, NY: Financial Guardian Publishing Company. Retrieved from https://books.google.co.in/ books/about/Tunnel_Thru_the Air_Or_Looking_Back_from html?id=1eRcta9cBocC\&redir esc $=\mathrm{y}$

6. Graham, B., \& Dodd, D. (1934). Security Analysis (880 p.). New York: McGraw-Hill.

7. Hamilton, W. P. (1926). The Stock Market Barometer (373 p.). New York and London: Harper and Brothers Publishers.

8. Hayes, M. G. (2008). The Economics of Keynes: A new guide to the General Theory. Edward Elgar Publishing. Retrieved from https:// econpapers.repec.org/bookchap/ pkeecbook/nggt.htm

9. Kuzheliev, M. O., Zherlitsyn, D. M., \& Zhytar, M. O. (2016). Formalization of the dynamic relations between the financial indicators of enterprises. Independent Auditor, 1826. Retrieved from https:// web.b.ebscohost.com/abstract?direct $=$ true\&profile $=$ ehost $\&$ scope $=$ site\&authtype $=$ crawler\&jrnl $=2306$ 0050\&asa $=\mathrm{Y} \& A N=118867643 \& \mathrm{~h}$ =gswa4fzQTLQzvqJcfleJLoHg0Ft rh0XuANtm4jqY7p8Mzc\%2fgxka LubAOYv9ZkW8g7TgDnTS2mVk IJH07dUrDfg\%3d\%3d\&crl=c\&res ultNs=AdminWebAuth\&resultLo $\mathrm{cal}=$ ErrCrlNotAuth\&crlhashurl=1 ogin.aspx\%3fdirect $\% 3$ dtrue $\% 26 \mathrm{pr}$ ofile $\% 3$ dehost $\% 26$ scope $\% 3$ dsite $\%$ 26authtype\%3dcrawler\%26jrnl\%3 d23060050\%26asa\%3dY\%26AN\% $3 \mathrm{~d} 118867643$

10. Kuzheliev, M., \& Britchenko. I. (2016). Theoretical and methodological aspects of formation of corporate control system in Ukraine. Economic Studies. Retrieved from https://ideas.repec.org/a/bas/ econst/y2016i2p3-28.html

11. Lane, G. (2007). Market Technicians Association Indicators. Retrieved on Nov. 23.

12. Lysenko, Yu. H., \& Zherlitsyn, D. M. (Eds.). (2017). Модернізація фінансових систем: методологія та інструменти управління [Modernizatsiia finansovykh system: metodolohiia ta instrument upravlinnia] (348 p.). Poltava: NAN Ukrainy). 
13. Meijers, H., Nomaler, Ö., \& Verspagen, B. J. (2019). Demand, credit and macroeconomic dynamics. A micro simulation model. Journal of Evolutionary Economics, 29(1), 337-364. https:/ link.springer.com/article/10.1007 \%2Fs00191-018-0553-9

14. Mints, O. Yu. (2017). Методологія моделювання інноваційних інтелектуальних систем прийняття рішень [Metodolohiia modeliuvannia innovatsiinykh intelektualnykh system pryiniattia rishen] (214 p.). Mariupol: Pryazovskyi derzhavnyi tekhnichnyi universytet. Retrieved from http://eir.pstu.edu/ handle/123456789/13748

15. Mirkin, Ya. М. (2002). Ценные бумаги и фондовый рынок [Tsennye bumagi i fondovyy rynok] (488 p.). Moscow: Perspektiva.

16. Murphy, J. J. (1986). Technical Analysis of the Futures Markets. New-York: New-York Institute of Finance.

17. National Bank of Ukraine (n.d.). Статистика [Statystyka]. Retrieved from https://bank.gov.ua/ control/uk/publish/article?art $\mathrm{id}=65162 \&$ cat_id $=36674$

18. National Securities and Stock Market Commission (n.d.). Official web-page. Retrieved from https:// www.nssmc.gov.ua
19. Nison, S. (2011). Strategies for Profiting with Japanese Candlestick Charts. Retrieved from https:// books.google.com.ua/books?id=Id yH1mkjtA4C\&printsec $=$ frontcover \&hl=ru\&source=gbs_ge_summary $\mathrm{r} \& \mathrm{cad}=0 \# \mathrm{v}=$ onepage $\& \mathrm{q} \& \mathrm{f}=$ false

20. PFTS ua-exchange (n.d.). Retrieved from http://pfts.ua/tradeinfo/90-xid-torgiv

21. Ponta, L., Pastore, S., \& Cincotti, S. (2006). Static and dynamic factors in an information-based multi-asset artificial stock market. Physica A: Statistical Mechanics and its Applications, 492.

22. S\&P Global. (n. d.). Retrieved from https://eu.spindices.com/ indices/equity/dow-jones-industrial-average

23. Shkliayev, L. O. (2012). Имитационное моделирование кредитного риска эмитента корпоративных облигаций [Imitataionnoye modelirovaniye kreditnigi riska emitenta korporativnykh obligatsiy]. Upravleniye ekonomicheskimi sistemami: elektronnyy nauchnyy zhurnal, 5. Retrieved from http://uecs. ru/index.php?option=com_fl exicontent\&view $=$ items\& $\mathrm{id}=1344: 2012-05-14-07-43-29$

24. Shkolnyk, I. O. (2008). Фінансовий ринок Украйни: сучасний стан і перспективи розвитку [Finansovyi rynok Ukrainy: suchasnyi stan i perspektyvy rozvytku] (348 p.). Sumy: Mriia-1.

25. State Statistics Service of Ukraine (n.d.). Retrieved from https:// ukrstat.gov.ua

26. Tarasiuk, D. S. (2013). Корпоративні облігації на фінансовому ринку України: становлення, сучасний стан та тенденції розвитку [Korporatyvni oblihatsii na finansovomu rynku Ukrainy: stanovlennia, suchasnyi stan ta tendentsii rozvytku]. Formuvannia rynkovoi ekonomiky v Ukraini, 2(29), 224232.

27. The World Bank (n.d.). World bank open data. Retrieved from https://data.worldbank.org

28. Wilder, J. W. (1978). New Concepts in Technical Trading Systems. Trend Research.

29. Williams, J. B. (1938). The Theory of Investment Value. Harvard University, Fraser Publishing.

30. Yartey, C. A. (2008). The Determinants of Stock Market Development in Emerging Economies: Is South Africa Different? (IMF Working paper WP/08/32). 